\title{
PENGARUH \\ KOMPETENSI PEGAWAI TERHADAP KINERJA PEGAWAI PADA KANTOR KELURAHAN SEMPAJA SELATAN KECAMATAN SAMARINDA UTARA
}

\author{
Dr. Djumar Soewito, M.Si \\ Dosen Tetap Ilmu Administrasi Negara FISIP UWGM Samarinda \\ Drs. H. Kusmayadi, M.M. \\ Dosen Tidak Tetap Ilmu Administrasi Negara FISIP UWGM Samarinda \\ Arie Andarie \\ Mahasiswa Ilmu Administrasi Negara FISIP UWGM Samarinda
}

\begin{abstract}
Abstrak
Menurut Undang-Undang Nomor 5 Tahun 2014 Tentang Aparatur Sipil Negara Pasal 1 Ayat 3, Pegawai Negeri Sipil (PNS) adalah warganegara Indonesia yang memenuhi syarat tertentu, diangkat sebagai pegawai Aparatur Sipil Negara (ASN) secara tetap oleh pejabat pembina kepegawaian untuk menduduki jabatan pemerintahan dan diatur pada Undang-Udang Nomor 5 Tahun 2014 tentang Aparatur Sipil Negara (ASN).

Permasalahan yang dibahas mengenai kompetensi pegawai berpengaruh terhadap kinerja pegawai pada Kantor Kelurahan Sempaja Selatan, Kecamatan Samarinda Utara. Penelitian ini bersifat verifikatif atau causalitas, dimana variabel-variabel tersebut akan dibuktikan dengan pengujian hipotesis. Jumlah populasi dan sampel yang diambil untuk penelitian adalah seluruhnya yaitu 20 responden secara sensus. Menggunakan Koefisien Korelasi Rank Spearman versi Sidney Siegel (1992:225). Diperoleh bahwa kompetensi pegawai berpengaruh terhadap kinerja pegawai pada Kantor Kelurahan Sempaja Selatan, Kecamatan Samarinda Utara. Hal ini dapat dibuktikan dari hasil perhitungan $r_{\mathrm{s}}$ tabel lebih besar $(0,450)$ daripada $r_{s}$ tabel kritis dengan tingkat signifikansi alfa $0,05(0,380)$.
\end{abstract}

Kata Kunci: kompetensi, kinerja, ASN, Sempaja Selatan Kota Samarinda

\begin{abstract}
According to Law Number 5 Year 2014 on State Civil Apparatus Article 1 Paragraph 3, Civil Servant (PNS) is a qualified Indonesian citizen, appointed as a permanent civil State Apparatus Officer (ASN) by a civil service officer to hold government office And regulated in Law No. 5 of 2014 on State Civil Apparatus (ASN).

The problems discussed about the competence of employees affect the performance of employees at the South Sempaja Urban Village Office, North Samarinda District.This research is verifikatif or causalitas, where the variables will be proved by testing the hypothesis.The total population and samples taken for the study were all 20 census respondents. Using Rank Spearman Rank Correlation Coefficient Sidney Siegel (1992: 225).Obtained that the competence of employees affect the performance of employees at the Office of South Sempaja Village, North Samarinda District.This can be proven from the results of calculation rs larger table $(0,450)$ than $r$ table critical with alpha significance level $0,05(0,380)$.
\end{abstract}

Keywords: competence, performance, ASN, Sempaja Selatan Kota Samarinda. 


\section{Latar Belakang}

Menurut Undang-Undang Nomor 5 Tahun 2014 Tentang Aparatur Sipil Negara Pasal 1 Ayat 3, Pegawai Negeri Sipil (PNS) adalah warganegara Indonesia yang memenuhi syarat tertentu, diangkat sebagai pegawai Aparatur Sipil Negara (ASN) secara tetap oleh pejabat pembina kepegawaian untuk menduduki jabatan pemerintahan.

Undang-Udang Nomor 5 Tahun 2014 tentang Aparatur Sipil Negara (ASN), tersirat amanat bahwa "Pegawai ASN berkedudukan sebagai unsur aparatur negara, yang melaksanakan kebijakan yang ditetapkan oleh pimpinan Instansi Pemerintah, harus bebas dari pengaruh dan intervensi semua golongan dan partai politik" bunyi Pasal 8 dan Pasal 9 Ayat (1 dan 2) Undang-Undang ini. Dan "Pegawai ASN berperan sebagai perencana, pelaksana, dan pengawas penyelenggaraan tugas umum pemerintahan dan pembangunan nasional melalui pelaksanaan kebijakan dan pelayanan publik yang profesional, bebas dari intervensi politik, serta bersih dari praktik korupsi, kolusi, dan nepotisme" bunyi Pasal 12 Undang-Undang ini. Kedudukan dan Peranan Pegawai Negeri Sipil (PNS) sangat penting dan menentukan karena pegawai negeri merupakan unsur aparatur negara dalam menyelenggarakan tugas-tugas pemerintahan dan pembangunan dalam rangka mencapai tujuan nasional. Anggaran Negara yang dibelanjakan untuk kepentingan Pegawai Negeri Sipil (PNS) dari tahun ke tahun mengalami kenaikan, namun hal tersebut belum diimbangi dengan peningkatan kompetensi dan kinerja yang tinggi bagi Pegawai Negeri Sipil (PNS).

Kompetensi Sumber Daya Manusia atau pegawai adalah kompetensi yang berhubungan dengan pengetahuan, keterampilan, kemampuan dan karakteristik kepribadian yang mempengaruhi secara langsung terhadap kinerjanya. Kompetensi Sumber Daya Manusia menurut hasil kajian Perrin (1990), yaitu memiliki kemampuan komputer (Eksekutif Lini), memiliki pengetahuan yang luas tentang visi, memiliki kemampuan mengantisipasi pengaruh perubahan dan memiliki kemampuan memberikan pendidikan tentang sumber daya manusia.

Dalam usaha meningkatkan dan mengembangkan kompetensi dan kinerja pegawai, ada 3 lembaga pemerintah yang berperan penting dalam hal tersebut, yakni Kementerian Pendayagunaan Aparatur Negara, Badan Kepegawaian Negara (BKN), dan Lembaga Administrasi Negara (LAN).

Berdasarkan Peraturan Pemerintah Nomor 73 Tahun 2005 Tentang Kelurahan Pasal 1 Ayat 5 "Kelurahan adalah wilayah kerja lurah sebagai perangkat daerah kabupaten/kota dalam wilayah kerja kecamatan". Kemudian berdasarkan Pasal 4 Ayat 1“ Lurah mempunyai tugas meyelenggarakan urusan pemerintahan, pembangunan dan kemasyarakatan".

Kelurahan dipimpin oleh seorang Lurah yang berstatus sebagai PNS dibantu oleh Bendahara dan seorang Sekretaris Lurah yang membawahi lima seksi, yaitu Seksi Tata Pemerintahan dan Ketertiban Umum, Seksi Kesejahteraan Rakyat, seksi Ekonomi dan Pembangunan, dan Seksi Kebersihan dan Lingkungan Hidup. Masing-masing bagian tersebut memiliki tugas pokok dan fungsinya masing-masing yang terkoordinasi dari setiap unsur tersebut. Apabila koordinasi tersebut berjalan dengan baik, maka kelurahan dalam melaksanakan tugas-tugasnya akan berhasil dengan baik.

Berdasarkan Peraturan Daerah Kota Samarinda Nomor 6 Tahun 2014 Pasal 2 Ayat 1 "Kelurahan yang dimekarkan dalam wilayah Kota Samarinda adalah pemecahan dari Kelurahan Induk yaitu Kelurahn Mesjid, Kelurahan Sungai Keledang, Kelurahan Sempaja Selatan dan Kelurahan Sungai Siring". Jadi, Kelurahan Sempaja Selatan, Kecamatan Samarinda Utara merupakan Kelurahan Induk yang dimekarkan menjadi 2 kelurahan, yaitu Kelurahan Sempaja Timur dan Kelurahan Sempaja Barat. 
Kantor Kelurahan Sempaja Selatan, Kecamatan Samarinda Utara adalah badan pemerintahan yang bergerak di bidang pelayanan masyarakat yang meliputi berbagai macam kegiatan administrasi yang menyangkut pelayanan terhadap pelayanan masyarakat. Pegawai Kelurahan Sempaja Selatan merupakan administrator di instansi pemerintah yang bertugas memberikan pelayanan kepada masyarakat secara efektif, efisien, transparan dan akuntabel dalam menyelenggarakan tugas negara. Kedudukan dan perannya yang penting menyebabkan pegawai-pegawainya selalu di tuntut agar memiliki kompetensi dan kinerja yang tinggi, pengabdian kepada masyarakat dan tidak mencari keuntungan apapun dalam melayani masyarakat dan melaksanakan tugas-tugasnya.

Berdasarkan pengamatan penulis pada Kelurahan Sempaja Selatan, Kecamatan Samarinda Utara, dalam kenyataannya belum menunjukkan pelayanan masyarakat yang optimal yang berkaitan dengan masalah kemampuan kerja dan kinerja para pegawai di kelurahan tersebut. Sebagian pegawai belum cakap menggunakan teknologi yang ada, masih lambat dalam menangani pekerjaan, terjadinya penundaan dalam penyelesaian pekerjaan dan kurang adanya koordinasi antara pimpinan dan pegawai.

\subsection{Perumusan Masalah}

Berdasarkan latar belakang masalah diuraikan di atas, maka permasalahan adalah "Apakah kompetensi pegawai berpengaruh terhadap kinerja pegawai pada Kantor Kelurahan Sempaja Selatan, Kecamatan Samarinda Utara".

\subsection{Tujuan Penelitian}

Berdasarkan laytar belakang dan maslaah penelitian, maka tujuan penelitian ini adalah sebagai berikut :

a. Untuk membuktikan kompetensi pegawai berpengaruh terhadap kinerja pegawai pada Kantor Kelurahan Sempaja Selatan, Kecamatan Samarinda Utara.

b. Untuk mengetahui faktor-faktor yang menghambat kinerja pegawai pada Kantor Kelurahan Sempaja Selatan, Kecamatan Samarinda Utara.

c. Untuk menguji hipotesis yang dirumuskan.

\section{Teori dan Konsep}

\subsection{Pengertian Kompetensi}

Kompetensi mencakup berbagai faktor teknis dan non teknis, kepribadian dan tingkah laku, soft skills dan hard skills, kemudian banyak dipergunakan sebagai aspek yang dinilai banyak perusahaan untuk merekrut karyawan ke dalam organisasi.

Training Agency (dalam Sedarmayanti, 2014:125) mengemukakan bahwa "kompetensi adalah Konsep luas, memuat kemampuan mentransfer keahlian dan kemampuan kepada situasi baru dalam wilayah kerja. Menyangkut organisasi dan perencanaan pekerjaan, inovasi dan mengatasi aktivitas rutin, kualitas efektivitas personel yang dibutuhkan di tempat berkaitan dengan rekan kerja, manajer serta pelanggan".

Kompetensi pada umumnya diartikan sebagai kecakapan, keterampilan, kemampuan. Kata dasarnya kompeten, berarti cakap, mampu atau terampil. Pada konteks manajemen sumber daya manusia, istilah kompetensi mengacu kepada atribut/karakteristik seseorang yang membuatnya berhasil dalam pekerjaan.

Menurut Mc. Clelland ( dalam Sedarmayanti, 2014:126) mengatakan bahwa "Competency (kompetensi) adalah karakteristik mendasar yang dimiliki seseorang yang berpengaruh langsung terhadap, atau dapat memprediksikan kinerja yang sangat baik". 
Dengan kata lain, kompetensi adalah apa yang outstanding performers lakukan lebih sering, pada lebih banyak situasi, dengan hasil yang lebih baik, daripada yang dilakukan penilai kebijakan. Kompetensi bisa dianalogikan seperti "gunung es" di mana keterampilan dan pengetahuan membentuk puncaknya yang berada di atas air. Bagian di bawah permukaan air tidak terlihat mata, namun menjadi fondasi dan memiliki pengaruh terhadap bentuk bagian yang berada di atas air. Peran sosial dan citra diri berada pada alam bawah sadarnya.

Karakteristik kompetensi dibedakan berdasarkan pada tingkat mana kompetensi tersebut dapat diajarkan. Keahlian dan pengetahuan biasanya dikelompokkan sebagai kompetisi di permukaan sehingga mudah tampak. Kompetisi ini biasanya mudah untuk dikembangkan dan tidak memerlukan biaya pelatihan yang besar untuk menguasainya. Kompetensi konsep diri, karakteristik pribadi dan motif sifatnya tersebunyi dan karena itu lebih sulit untuk dikembangkan atau dinilai. Untuk mengubah motif dan karakteristik pribadi masih dapat dilakukan, namun prosesnya panjang, sulit dan mahal. Cara yang paling hemat bagi organisasi untuk memiliki kompetensi ini adalah melalui proses seleksi karakter.

Menurut Mitrani (1995:21), mengatakan bahwa "Kompetensi adalah suatu sifat dasar seseorang yang dengan sendirinya berkaitan dengan pelaksanaan suatu pekerjaan secara efektif atau sangat berhasil".

Sedangkan menurut Michael Zwell (2000:25) mengemukakan bahwa "ada lima kategori kompetensi, yang terdiri dari task achievement, relationship, personal attribute, managerial, dan leadership".

1) Task achievement merupakan kategori kompetensi yang berhubungan dengan kinerja baik. Kompetensi yang berkaitan dengan task achievement ditunjukkan oleh orientasi pada hasil, mengelola kinerja, mepengaruhi, inisiatif, efisensi produksi, fleksibilitas, inovasi, peduli kepada kualitas, perbaikan berkelanjutan, dan keahlian teknis.

2) Relationship merupakan kategori kompetensi yang berhubungan dengan komunikasi dan bekerja baik dengan orang lain dan memuaskan kebutuhannya. Kompetensi yang berhubungan dengan relationship meliputi: kerja sama, orientasi pada pelayanan, kepedulian antar pribadi, kecerdasan organisasional, membangun hubungan, penyelesaian konflik, perhatian pada komunikasi dan sensitivitas lintas budaya.

3) Personal attribute merupakan kompetensi intrinsic individu dan menghubungkan bagaimana orang berpikir, merasa, belajar dan berkembang. Personal attribute merupakan kompetensi yang meliputi: integritas dan kejujuran, pengembangan diri, ketegasan, kualitas keputusan, manajemen stress, berpikir analitis, dan berpikir konseptual.

4) Managerial merupakan kompetensi yang secara spesifik berkaitan dengan pengelolaan, pengawasan dan mengembangkan orang. Kompetensi manajerial berupa: memotivasi, memberdayakan, dan mengembangkan orang lain.

5) Leadership merupakan kompetensi yang berhubungan dengan memimpin organisasi dan orang untuk mencapai maksud, visi, dan tujuan organisasi. Kompetensi berkenaan dengan leadership meliputi kepemimpinan visioner, berpikir strategis, orientasi kewirausahaan, manajemen perubahan, membangun komitmen organisasional, membangun focus dan maksud. 
Kompetensi termasuk karakteristik manusia yang paling dalam seperti motif, sifat dan sikap atau merupakan karakteristik yang dengan mudah dapat diamati seperti keterampilan atau pengetahuan.

\subsection{Pengertian Kinerja}

Kinerja organisasi dewasa ini telah menjadi sorotan publik, hal ini karena telah timbulnya iklim demokratisasi dan keterbukaan. Di samping itu, selama ini pengukuran keberhasilan maupun kegagalan dari suatu organisasi dalam menjalankan tugas pokok dan fungsinya sulit dilakukan secara objektif. Kesulitan ini karena belum pernah disusun sistem pengukuran kinerja yang dapat menginformasikan tingkat suatu keberhasilan suatu organisasi.

Istilah kinerja (performance) menurut The Scriber dalam Kamus Bantam English Dictionary yang dikemukakan oleh Prawirosentono (1992:2) bahwa "Kinerja (performance) dari akar kata to perform yang mempunyai beberapa entries sebagai berikut":

1) Melakukan, menjalankan, dan melaksanakan.

2) Memenuhi, menjalankan kewajiban suatu nazar

3) Menjalankan suatu karakter dalam suatu permainan

4) Menggambarkan dengan suara atau alat musik

5) Melaksanakan atau menyempurnakan suatu tanggung jawab

6) Melakukan suatu kegiatan dalam suatu permainan

7) Memainkan pertunjukkan musik

8) Melakukan sesuatu yang diharapkan oleh seseorang atau mesin.

Pendapat lain dikemukakan oleh Suntoro (1999:12) bahwa "Kinerja adalah hasil kerja yang dicapai oleh seseorang atau kelompok orang dalam suatu organisasi sesuai dengan wewenang dan tanggung jawab masing-masing dalam rangka mencapai tujuan organisasi yang bersangkutan secara legal, tidak melanggar hukum dan sesuai dengan moral dan etika".

Menurut Simanjuntak (2005:103) mengatakan bahwa "Kinerja Individu adalah tingkat pencapaian atau hasil kerja seseorang dari sasaran yang harus dicapai atau tugas yang harus dilaksanakan dalam kurun waktu tertentu".

Menurut Mangkunegara (2005:9) mengatakan bahwa "Kinerja adalah merupakan hasil kerja secara kualitas dan kuantitas yang dicapai oleh seseorang dalam melaksanakan fungsinya sesuai dengan tanggung jawab yang diberikan kepadanya".

Sedangkan menurut Bernadian, John H dan Joyce E. A. Russell (1993:379) berpendapat bahwa "Kinerja didefinisikan sebagai catatan mengenai out come yang dihasilkan dari suatu aktivitas tertentu, selama kurun waktu tertentu pula".

Lijan Poltak Sinambela, dkk dalam (2012:5) mengemukakan bahwa "Kinerja pegawai didefinisikan sebagai kemampuan pegawai dalam melakukan sesuatu keahlian tertentu. Kinerja pegawai sangatlah perlu, sebab kinerja ini akan diketahui seberapa jauh kemampuan pegawai dalam melaksanakan tugas yang dibebankan kepadanya. Untuk itu diperlukan penentuan kriteria yang jelas dan terukur serta ditetapkan secara bersamasama yang dijadikan sebagai acuan".

Menurut Prawirosentono dalam Lijan Poltak Sinambela (2012:5) berpendapat bahwa "Kinerja adalah hasil kerja yang dicapai oleh seseorang atau sekelompok orang 
dalam suatu organisasi, sesuai dengan wewenang dan tanggung jawab masing-masing, dalam rangka upaya mencapai tujuan organisasi bersangkutan secara legal, tidak melanggar hukum dan sesuai dengan moral dan etika".

Sedangkan menurut Rivai, Basri dalam Lijan Poltak Sinambela (2012:6) mengemukakan bahwa "Kinerja adalah hasil atau tingkat keberhasilan seseorang atau keseluruhan selama periode tertentu di dalam melaksanakan tugas dibandingkan dengan berbagai kemungkinan, seperti standar hasil kerja, target atau sasaran atau kriteria yang telah ditentukan terlebih dahulu dan telah disepakati bersama".

\subsection{Teori Penghubung}

Adapun teori yang digunakan peneliti untuk menghubungkan antara teori variabel independen dan variabel dependen adalah Menurut Spencer dan Spencer (dalam Palan, 2007:6), mengemukakan bahwa "Kompetensi merujuk kepada karakteristik yang mendasari perilaku yang menggambarkan motif, karakteristik pribadi (ciri khas), konsep diri, nilai-nilai, pengetahuan atau keahlian yang dibawa seseorang yang berkinerja unggul (superior performer) di tempat kerja".

Menurut Syaiful F. Prihadi (2004:105) mengatakan "Kompetensi menghasilkan kinerja yang efektif dan atau superior"

Dari penjelasan tersebut berarti kompetensi mempunyai hubungan yang erat dengan kinerja. Bisa dikatakan apabila pegawai memiliki kompetensi di bidangnya, maka pegawai tersebut akan meningkatkan kinerja yang efektif.

Betapa pentingnya kinerja bagi instansi pemerintah maupun perusahaan sehingga pengembangan pegawai berbasis kompetensi merupakan salah satu upaya yang dapat meningkatkan kinerja, karena pengembangan pegawai berbasis kompetensi merupakan wujud perhatian dan pengakuan pimpinan kepada pegawainya yang menunjukkan kemampuan kerja, kerajinan, dan kepatuhan serta disiplin kerja. Pengolahan karyawan yang efektif melalui cara peningkatan keterampilan dan keahlin pegawai atau peningkatan kompetensi dan pemberian motivasi juga memberikan kesempatan pada pegawai untuk dapat meningkatkan prestasi kerja dan berkembang lebih maju apabila kompetensi dan mootivasi diberikan secara tepat dan peningkatan kompetensi disesuaikan dengan pendidikan yang dimiliki oleh pegawai diharapkan pegawai dapat melakukan pekerjaannya dengan baik, produktivitas kerja meningkat dan memberikan pelayanan yang terbaik kepada masyarakat maka hal ini akan mempertimbangkan adanya kecenderungan semangat kerja yang tinggi dan juga meningkatkan loyalitas pegawai kepada pemerintahan.

Jadi jelaslah bahwa kompetensi dan kinerja saling berhubungan. Hal ini harus diperhatikan karena terdapat hubungan yang saling mempengaruhi antara keduanya. Disatu pihak kompetensi dapat meningkatkan kinerja, sehingga pengembangan kompetensi yang baik akan dapat meningkatkan kinerja pegawai tersebut.

\subsection{Hipotesis}

Adapun hipotesis penelitian ini yakni "diduga Kompetensi Pegawai Berpengaruh Terhadap Kinerja Pegawai Kantor Kelurahan Sempaja Selatan, Kecamatan Samarinda Utara".

\subsection{Definisi Konsepsional}

Definisi konsepsional penelitian ini yakni kompetensi adalah kemampuan, keterampilan, dan karakteristik yang mendasari perilaku seseorang untuk melaksanakan tugas dan kewajiban yang dibebankan kepadanya sesuai dengan hasil yang diharapkan. Kompetensi terlihat dalam dimensi pengetahuan, keterampilan, konsep diri dan nilai- 
nilai, karakteristik pribadi, dan motif yang memicu tindakan seseorang. Sedangkan kinerja adalah suatu hasil kerja secara kualitas dan kuantitas yang dapat dicapai oleh seorang pegawai dalam suatu organisasi sesuai dengan tanggung jawab yang telah diberikan kepadanya dan memenuhi standar dan kriteria yang telah ditetapkan dalam kurun waktu tertentu.

\subsection{Definisi Operasional}

Pada bagian ini digunakan indikator dari variabel independen (kompetensi) yakni Pengetahuan, Keterampilan, dan Perilaku. Sedangkan indikator dari variabel dependen (kinerja) yakni Hasil kerja, Hubungan kerja, dan Dispilin Kerja.

\section{Metode Penelitian}

\subsection{Jenis Penelitian}

Penelitian yang bersifat verifikatif atau causalitas, yaitu penelitian yang mencari hubungan sebab akibat diantara dua vaiabel yang diteliti.

\subsection{Populasi dan Sampel}

Mengingat penelitian ini menggunakan sensus, maka responden adalah seluruh pegawai yang ada pada Kantor Kelurahan Sempaja Selatan, Kecamatan Samarinda Utara yang berjumlah sebanyak 19 orang pegawai yang terdiri dari 1 orang Lurah, 1 orang Sekretaris Lurah, 1 orang Bendahara, 4 orang Kasi (Kepala Seksi), dan 12 orang staf. Dengan demikian, yang menjadi populasi dan sekaligus dijadikan sampel adalah sebanyak 19 orang responden.

\subsection{Gejala yang Dihadapi}

Pada penelitian ini, peneliti hanya mengukur gejala kontinumnya saja. Karena berdasarkan tingkatannya dapat diukur kualitasnya dan dihitung kuantitasnya.

\subsection{Alat Pengukur Data}

Berdasarkan gejala yang dihadapi dalam penelitian ini yaitu gejala kontinum, maka peneliti menggunakan skala ordinal dengan jenjang 3, yakni Responden yang menjawab a diberi nilai 3 , Responden yang menjawab b diberi nilai 2 , dan Responden yang menjawab c diberi nilai 1 .

\subsection{Tekhnik Pengumpulan Data}

Dalam penelitian ini, untuk memperoleh data yang dibutuhkan, peneliti menggunakan tekhnik pengumpulan data berupa Kepustakaan, Observasi, dan Angket.

\subsection{Analisis Data}

Dalam penelitian verifikatif atau kausalitas menggunakan teknik analisis kuantitatif atau statistik. Untuk menguji hipotesis hubungan sebab akibat diantara dua variabel, peneliti menggunakan analisis data Koefisien Korelasi Rank Spearmen yang dikutip dari Sidney Siegel (1992:225) dengan rumus sebagai berikut : 
berikut:

Apabila ditemukan berangka tidak sama, maka dipergunakan rumus sebagai

$$
\mathrm{r}_{\mathrm{s}}=1-\frac{6 \sum_{\mathrm{t}=1}^{\mathrm{N}} \mathrm{d}_{\mathrm{t}}^{2}}{\mathrm{~N}^{3}-\mathrm{N}}
$$

Apabila ditemukan berangka sama, maka dipergunakan rumus sebagai berikut:

$$
\begin{gathered}
\mathrm{r}_{\mathrm{s}}=\frac{\sum \mathrm{x}^{2}+\sum \mathrm{y}^{2}-\sum \mathrm{d}_{\mathrm{i}}^{2}}{2 \sqrt{\sum \mathrm{x}^{2} \cdot \sum \mathrm{y}^{2}}} \\
\sum \mathrm{X}^{2}-\frac{\mathrm{n}^{3}-\mathrm{n}}{12}-\sum \mathrm{Tx} \\
\sum \mathrm{Y}^{2}=\frac{\mathrm{n}^{3}-\mathrm{n}}{12}-\sum \mathrm{Ty} \\
\mathrm{T}=\frac{\mathrm{t}^{3}-\mathrm{t}}{12}
\end{gathered}
$$

Keterangan :

$\mathrm{r}_{\mathrm{s}} \quad$ : Koefisien korelasi rank spearmen

$\mathrm{N} \quad$ : Jumlah sampel (responden)

$\mathrm{T} \quad$ : Faktor korelasi

t : Jumlah himpunan skor variabel yang berangka sama

1 : Bilangan tetap

12 : Bilangan tetap

X : Independen Variabel

$\mathrm{Y} \quad$ : Dependen variabel

\section{Gambaran Umum Lokasi Penelitian}

\subsection{Sejarah Kelurahan Sempaja Selatan}

Kelurahan Sempaja terbentuk sejak Tahun 1981, dibawah kecamatan Samarinda Ilir yang luasnya kurang lebih 24.000 Hektar atau $240 \mathrm{Km}$ persegi $(20 \mathrm{Km}$ x $12 \mathrm{Km}$ ). 
Pada tahun 1996 terjadi pemekaran kecamatan yaitu Kecamatan Samarinda Ilir dan Kecamatan Samarinda Utara. Untuk Kelurahan Sempaja masuk dalam Kecamatan Samarinda Utara.

Pada tanggal 6 Juli tahun 2006 terjadi pemekaran kelurahan, yaitu Kelurahan Sempaja Selatan dan Kelurahan Sempaja Utara. Dalam pemekaran tersebut Kelurahan Sempaja Selatan mempunyai luas wilayah kurang lebih $35.34 \mathrm{Km}^{2}$ terdiri 90 RT dengan batas wilayah sebelah utara Kelurahan Sempaja Utara, sebelah timur Kelurahan Temindung Permai, sebelah Selatan Kelurahan Gunung Kelua, sebelah barat Kelurahan Gunung Kelua.

Kemudian karena terlalu banyaknya masyarakat yang harus dilayani di wilayah Kelurahan Sempaja Selatan, maka terhitung pada bulan Januari 2015 berdasarkan Perda Kota Samarinda Nomor 6 Tahun 2014, Kelurahan Sempaja Selatan kembali dimekarkan menjadi tiga kelurahan yaitu Kelurahan Sempaja Selatan sebagai kelurahan induk dan dua kelurahan pemekaran/ kelurahan baru yaitu Kelurahan Sempaja Timur dan Kelurahan Sempaja Barat.

\subsection{Letak Geografis Kelurahan Sempaja Selatan}

Kelurahan Sempaja Selatan memiliki luas wilayah 373 Ha yang terdiri dari 33 Rukun Tetangga (RT). Alamat Kantor Kelurahan Sempaja Selatan terletak di Jl. Karya Baru No. 44 RT. 011, Samarinda. Adapun batas wilayah Kelurahan Sempaja Selatan adalah sebagai berikut :

Tabel 1. Batas Wilayah

\begin{tabular}{|l|l|l|}
\hline \multicolumn{1}{|c|}{ Batas } & \multicolumn{1}{c|}{ Kelurahan } & \multicolumn{1}{c|}{ Kecamatan } \\
\hline Sebelah Utara & Sempaja Barat dan Sempaja Timur & Samarinda Kota \\
\hline Sebelah Selatan & Gunung Kelua & Samarinda Ulu \\
\hline Sebelah Timur & Temindung Permai & Sungai Pinang \\
\hline Sebelaah Barat & Gunung Kelua & Samarinda Ulu \\
\hline
\end{tabular}

Sumber : Profil Kelurahan Sempaja Selatan

\subsection{Visi dan Misi Kelurahan Sempaja Selatan}

1) Visi Kelurahan Sempaja Selatan

Mewujudkan Pelayanan Yang Berkualitas, Guna Menunjang Pelayanan Prima Dalam Upaya Meningkatkan Partisipasi Masyarakat Yang Aktif Dan Mandiri”.

2) Misi Kelurahan Sempaja Selatan
a) Meningkatkan Kualitas Sumberdaya Manusia (Sdm) Pegawai Kelurahan
b) Meningkatkan Koordinasi Kerja Secara Internal Maupun External
c) Meningkatkan Partisipasi Masyarakat Dalam Mendukung Program Pembangunan Di Wilayah Kelurahan Sempaja Selatan
d) Meningkatkan Kesadaran Hukum, Kesehatan Lingkungan Dan Kesejahteraan Masyarakat.




\section{Analisis Data Dan Pengujian Hipotesis}

\subsection{Analisis Data}

Untuk menemukan jawaban pengaruh kompetensi pegawai terhadap kinerja pegawai pada Kantor Kelurahan Sempaja Selatan, Kecamatan Samarinda Utara, peneliti akan melakukan analisis data dengan menggunakan Koefisien Korelasi Rank Spearman $\left(\mathrm{r}_{\mathrm{s}}\right)$.

Tabel 22. Skor dan Ranking hasil berdasarkan distribusi skor untuk variabel $X$ dan variabel Y.

\begin{tabular}{|c|c|c|c|c|c|c|}
\hline \multirow{2}{*}{ Responden ( N) } & \multicolumn{2}{|c|}{ Jumlah Skor } & \multicolumn{2}{|c|}{ Ranking } & \multirow{2}{*}{$\mathbf{d}_{\mathbf{i}}$} & \multirow{2}{*}{$d_{i}^{2}$} \\
\hline & $\mathbf{X}$ & $\mathbf{Y}$ & $\mathbf{X}$ & $\mathbf{Y}$ & & \\
\hline 1 & 26 & 25 & 15,5 & 10 & 5,5 & 30,25 \\
\hline 2 & 22 & 25 & 3,5 & 10 & $-6,5$ & 42,25 \\
\hline 3 & 26 & 25 & 15,5 & 10 & 5,5 & 30,25 \\
\hline 4 & 26 & 23 & 15,5 & 7,5 & 8,5 & 72,25 \\
\hline 5 & 25 & 21 & 11,5 & 3 & 8 & 64 \\
\hline 6 & 23 & 21 & 5,5 & 3 & 2,5 & 6,25 \\
\hline 7 & 21 & 22 & 2 & 5,5 & $-3,5$ & 12,25 \\
\hline 8 & 23 & 26 & 5,5 & 13,5 & -8 & 64 \\
\hline 9 & 26 & 27 & 15,5 & 17,5 & -2 & 4 \\
\hline 10 & 26 & 27 & 15,5 & 17,5 & -2 & 4 \\
\hline 11 & 27 & 27 & 19 & 17,5 & 1,5 & 2,25 \\
\hline 12 & 24 & 21 & 8,5 & 3 & 5,5 & 30,25 \\
\hline 13 & 24 & 26 & 8,5 & 13,5 & -5 & 25 \\
\hline 14 & 24 & 26 & 8,5 & 13,5 & -5 & 25 \\
\hline 15 & 18 & 20 & 1 & 1 & 0 & 0 \\
\hline 16 & 25 & 26 & 11,5 & 13,5 & -2 & 4 \\
\hline 17 & 22 & 23 & 3,5 & 7,5 & -4 & 16 \\
\hline 18 & 26 & 22 & 15,5 & 5,5 & 10 & 100 \\
\hline 19 & 24 & 27 & 8,5 & 17,5 & -9 & 81 \\
\hline Jumlah & 458 & 460 & & & $\mathbf{0}$ & 613 \\
\hline
\end{tabular}

Sumber data : Pengolahan data

Berdasarkan tabel di atas dapat diketahui bahwa $\sum d_{i^{2}}=613$, dan juga terdapat himpunan skor variabel yang berangka sama, yaitu sebagai berikut :

- Terdapat 5 himpunan skor pada variabel kompetensi pegawai (X) yang berangka sama, yaitu :

1. Skor 22 dengan ranking 3,5 terdapat 2 himpunan yang berangka sama

2. Skor 23 dengan ranking 5,5 terdapat 2 himpunan yang berangka sama 
3. Skor 24 dengan ranking 8,5 terdapat 4 himpunan yang berangka sama

4. Skor 25 dengan ranking 11,5 terdapat 2 himpunan yang berangka sama

5. Skor 26 dengan ranking 15,5 terdapat 6 himpunan yang berangka sama

- Terdapat 6 himpunan skor pada variabel kinerja pegawai (Y) yang berangka sama, yaitu :

1. Skor 21 dengan ranking 3 terdapat 3 himpunan yang berangka sama

2. Skor 22 dengan ranking 5,5 terdapat 2 himpunan yang berangka sama

3. Skor 23 dengan ranking 7,5 terdapat 2 himpunan yang berangka sama

4. Skor 25 dengan ranking 10 terdapat 3 himpunan yang berangka sama

5. Skor 26 dengan ranking 13,5 terdapat 4 himpunan yang berangka sama

6. Skor 27 dengan ranking 17,5 terdapat 4 himpunan yang berangka sama

Selanjutnya peneliti akan mencari nilai $\sum \mathrm{X}^{2}$ dan $\sum \mathrm{Y}^{2}$, dimana masing-masing jumlah nilai tersebut akan ditentukan dari jumlah Faktor Korelasi (T) pada setiap variabel dengan rumus sebagai berikut :

$$
\begin{aligned}
\Sigma \mathrm{X}^{2} & =\frac{\mathrm{N}^{3}-\mathrm{N}}{12}-\sum \mathrm{Tx} \\
& =\frac{19^{3}-19}{12}-\left(\frac{2^{3}-2}{12}+\frac{2^{3}-2}{12}+\frac{4^{3}-4}{12}+\frac{2^{3}-2}{12}+\frac{6^{3}-6}{12}\right) \\
& =\frac{6859-19}{12}-\left(\frac{8-2}{12}+\frac{8-2}{12}+\frac{64-4}{12}+\frac{8-2}{12}+\frac{216-6}{12}\right) \\
& =\frac{6840}{12}-\left(\frac{6}{12}+\frac{6}{12}+\frac{60}{12}+\frac{6}{12}+\frac{210}{12}\right) \\
& =570-(0,5+0,5+5+0,5+17,5) \\
& =570-24 \\
& =546 \\
\sum \mathrm{Y}^{2} & =\frac{\mathrm{N}^{3}-\mathrm{N}}{12}-\sum \mathrm{Ty} \\
& =\frac{19^{3}-19}{12}-\left(\frac{3^{3}-3}{12}+\frac{2^{3}-2}{12}+\frac{2^{3}-2}{12}+\frac{3^{3}-3}{12}+\frac{4^{3}-4}{12}+\frac{4^{3}-4}{12}\right) \\
& =\frac{6859-19}{12}-\left(\frac{27-3}{12}+\frac{8-2}{12}+\frac{8-2}{12}+\frac{27-3}{12}+\frac{64-4}{12}+\frac{64-4}{12}\right) \\
& =\frac{6840}{12}-\left(\frac{24}{12}+\frac{6}{12}+\frac{6}{12}+\frac{24}{12}+\frac{60}{12}+\frac{60}{12}\right) \\
& =570-(2+0,5+0,5+2+5+5) \\
& =570-15 \\
& =555
\end{aligned}
$$


Berdasarkan hasil yang didapatkan dari perhitungan di atas, maka korelasinya dapat dihitung dengan rumus sebagai berikut :

$$
\begin{aligned}
\qquad \mathrm{rs} & =\frac{\sum \mathrm{X}^{2}+\sum \mathrm{Y}^{2}-\sum \mathrm{d}_{\mathrm{i}}^{2}}{2 \cdot \sqrt{\sum \mathrm{x}^{2} \cdot \sum \mathrm{y}^{2}}} \\
& =\frac{(546+555)-613}{2 \cdot \sqrt{546.555}} \\
& =\frac{1101-613}{2 \cdot \sqrt{303030}} \\
& =\frac{488}{2 \cdot 550,48} \\
& =\frac{488}{1100,96} \\
& =0,443
\end{aligned}
$$

\subsection{Pengujian Hipotesis}

Diketahui tingkat korelasi $\left(r_{s}\right)$ perhitungan dengan $\mathrm{N}=19$ adalah 0,443 dan $r_{s}$ tabel kritis pada tingkat signifikansi alfa 0,05 adalah 0,391. Jadi, jika dibandingkan maka $r_{\mathrm{s}}$ perhitungan lebih besar daripada $r_{s}$ tabel kirits $(0,443>0,391)$. Dengan demikian, hipotesis yang dirumuskan peneliti dapat diterima, yaitu Kompetensi Pegawai Berpengaruh Terhadap Kinerja Pegawai Kantor Kelurahan Sempaja Selatan, Kecamatan Samarinda Utara.

\section{Kesimpulan Dan Saran}

\subsection{Kesimpulan}

Berdasarkan hasil penetilian yang telah dilakukan pada Kelurahan Sempaja Selatan, Kecamatan Samarinda Utara dengan jumlah populasi dan sampel sebanyak 19 responden, peneliti dapat menyimpulkan bahwa :

1. Berdasarkan total skor dari variabel $\mathrm{X}$ dan variabel $\mathrm{Y}$, para pegawai pada Kantor Kelurahan Sempaja Selatan, Kecamatan Samarinda Utara memiliki kompetensi yang cukup baik dengan menghasilkan kinerja yang cukup baik pula.

2. Berdasarkan hasil perhitungan yang telah dilakukan, dapat dinyatakan bahwa kompetensi pegawai berpengaruh terhadap kinerja pegawai pada Kantor Kelurahan Sempaja Selatan, Kecamatan Samarinda Utara. Hal ini dapat dibuktikan dari hasil perhitungan $r_{s}$ lebih besar $(0,443)$ daripada $r_{s}$ tabel kritis dengan tingkat signifikansi alfa $0,05(0,391)$.

3. Hipotesis yang dirumuskan oleh peneliti dapat diterima, yaitu "Diduga Kompetensi Pegawai Berpengaruh Terhadap Kinerja Pegawai Kantor Kelurahan Sempaja Selatan, Kecamatan Samarinda Utara"

\section{B. Saran}


Sebagai sumbangan pemikiran mengenai pengaruh kompetensi pegawai terhadap kinerja pegawai pada Kantor Kelurahan Sempaja Selatan, Kecamatan Samarinda Utara, peneliti ingin memberi saran-saran sebagai berikut :

a. Perlu diadakannya kegiatan mengikuti Pendidikan dan Pelatihan (Diklat) untuk meningkatkan kompetensi pegawai agar dapat menghasilkan kinerja yang tinggi.

b. Perlunya peran pemimpin yang selalu memberikan motivasi kepada bawahannya agar selalu memiliki inisiatif dan semangat untuk bekerja.

c. Perlunya pemenuhan kebutuhan pegawai di tempat kerja, agar dalam menjalankan tugas negara khususnya dalam bidang administrasi negara dapat berjalan dengan lancar.

d. Perlunya pembenahan tata letak ruang kantor yang baik agar para pegawai dapat bekerja dengan rasa aman dan nyaman, sehingga masyarakat dapat melihat bahwa Kantor Kelurahan Sempaja Selatan memiliki manajemen yang baik.

\section{Daftar Pustaka}

Buku-buku :

A.A. ANWAR PRABU MANGKUNEGARA, 2005, Evaluasi Kinerja Sumber Daya Manusia, Refika Aditama, Bandung.

ALAIN MITRANI, 1995, Manajemen Sumber Daya Manusia Berbasis Kompetensi (terjemahan), PT. Intermasa, Jakarta.

E.T. RUSEFFENDI, 1994, Dasar-dasar Penelitian Pendidikan dan Non Eksakta Lainnya, Semarang Press, Semarang.

IQBAL HASAN, 2006, Metode-Metode Penelitian Ilmiah, Gunung Agung, Jakarta.

IRAWAN SOEHARTONO, 2004, Metode Penelitian Sosial Suatu Teknik Penelitian Bidang Kesejahteraan Sosial dan Ilmu Sosial Lainnya, PT. Remaja Rosdakarya, Bandung.

ISMAIL NAWAWI UHA, 2013, Budaya Organisasi Kepemimpinan dan Kinerja Proses Terbentuk Tumbuk Kembang Dinamika dan Kinerja Organisasi, Kencana Prenadamedia Group, Jakarta.

KAELAN M.S, 2005, Metode Penelitian Kualitatif Bidang Filsafat, Paradigma, Yogyakarta.

KERLINGER, 2006, Asas-Asas Penelitian Behavioral, Edisi Ketiga, Gajah Mada University Press, Yogyakarta.

LIJAN POLTAK SINAMBELA, 2012, Kinerja Pegawai Teori Pengukuran dan Implikasi, Graha Ilmu, Yogyakarta.

MASRI SINGARIMBUN, Sofian Effendi, 1995, Metode Penelitian Survei, LP3ES, Jakarta.

MARGONO, 2004, Metodologi Penelitian Pendidikan, Rineka Cipta, Jakarta.

MIFTAH THOHA, 2014, Manajemen Kepegawaian Sipil di Indonesia, Edisi Kedua, Cetakan Kelima, Prenadamedia Group, Jakarta.

PAYAMAN J. SIMANJUNTAK, 2005, Manajemen dan Evaluasi Kinerja, Fakultas Ekonomi UI, Jakarta. 
P. JOKO SUBAGIA, 2004, Pengantar Metodologi Riset Sosial, Alumni, Bandung.

R. PALAN, 2007, Competency Management Teknik Mengimplementasikan Manajemen SDM berbasis Kompetensi untuk Meningkatkan Daya Saing Organisasi (Terjemahan Octa Melia Jalal), Penerbit PPM, Jakarta.

SEDARMAYANTI, 2014, Manajemen Sumber Daya Manusia Reformasi Birokrasi dan Manajemen Pegawai Negeri Sipil, Cetakan ke Tujuh, PT. Refika Aditama, Bandung.

SUGIYONO, 2010, Metode Penelitian Pendidikan, Alfabeta, Bandung.

SUKARDI, 2006, Metode Penelitisn Sosial, Cetakan ke 4, PT. Remaja Rosdakarya, Bandung.

SURYABRATA, 2000, Metodologi Penelitian, PT Raja Grafindo Persada, Jakarta.

SUTRISNO HADI, 2004, Metode Research, Andi, Yogyakarta.

ULBER SILALAHI, 2012, Metode Penelitian Sosial, Cetakan Ketiga, PT. Refika Aditama, 2012.

WIBOWO, 2007, Manajemen Kinerja, PT. Raja Grafindo Persada, Jakarta.

\section{Penelitian:}

EMMYAH, 2009, Pengaruh Kompetensi Terhadap Kinerja Pegawai Pada Politeknik Negeri Ujung Pandang, Tesis Sekolah Tinggi Ilmu Administrasi Negara Lembaga Administrasi Negara Makassar.

MEITY NOVIANTI, 2014, Pengaruh Sarana dan Prasarana Sekolah Terhadap Prestasi Belajar Siswa Siswi di SMP Negeri 5 Loleng Kecamatan Kota Bangun, Skripsi Universitas Widya Gama Mahakam Samarinda.

Artikel :

ABDUL MALIK, 2013, Teknik Pengumpulan Data Angket atau Kuesioner, Artikel(http://pokoe-mimpiku.blogspot.co.id/2013/05/teknik-pengumpulandata-angket-atau.html\#.VxPA7TFIp3w), (diakses pada tanggal 18 April 2016).

BKN.go.id

MENPAN.go.id

NADYA RACHMAWATI, 2011, Teknik Pengumpulan Data Observasi, Artikel (http://rachmawatinada.blogspot.co.id/2011/11/teknik-pengumpulan-data observasi.html), (diakses pada tanggal 18 April 2016).

LAN.go.id 